GLOBAL JOURNAL OF AGRICULTURAL SCIENCES VOL. 19, 2020: 27-32

COPYRIGHTC BACHUDO SCIENCE CO. LTD PRINTED IN NIGERIA ISSN 1596-2903 www.globaljournalseries.com, Email: info@globaljournalseries.com

\title{
IMPACT OF PALM OIL MILL EFFLUENT (POME) ON THE POPULATIONS OF RHIZOBIUM AND MELOIDOGYNE SPECIES IN AWKA, NIGERIA.
}

OKOLIE, HENRY, EKWURIBE, CHUKWUEMEKA, OBIDIEBUBE, EUCHARIA, AND OBASI, CHIAMAKA,

(Received 16 July 2019; Revision Accepted 14 August 2019)

\begin{abstract}
The impact of palm oil mill effluent (POME) on the populations of Rhizobium and Meloidogyne species was tested at the Teaching and Research Farm of Nnamdi Azikiwe University Awka, Nigeria. Three cowpea cultivars ,Dan Kano, Borno local and Sokoto local were used as target crops on plots that received $0 \mathrm{l} / \mathrm{ha}$ (control), $4000 \mathrm{l} / \mathrm{ha}, 6000 \mathrm{l} / \mathrm{ha}$ and $80001 /$ ha levels of POME applications. The treatments combinations were randomized within each block and replicated three times. Generally, increasing level of POME application increased number of functional root nodules in all the cultivars, but decreased length of roots and number of non- functional nodules. Nematode populations drastically decreased with increase in POME quantities. Both Rhizobium and Meloidogyne species compete for establishment sites on cowpea roots and high POME rates decreased Nematode population which is why all the three cowpea cultivars had their highest yields at $8000 \mathrm{l} / \mathrm{ha}$ POME application rate. So POME, an organic waste from oil palm processing can be used at up to $8000 \mathrm{l} / \mathrm{ha}$ to effectively control obnoxious root knot nematode and enrich soil for crop cultivation especially Sokoto local cowpea cultivar.
\end{abstract}

KEYWORDS: POME (palm oil mill effluent), Rhizobium, Meloidogyne liters/hectare, cowpea cultivars

\section{INTRODUCTION}

Cowpea is a grain legume of the family Fabaceae. It is one of the most popular and important crops in the tropics (Langyintuo et al., 2003). It is basically grown in the third world for its cheap source of dietary protein and a supplement for meat. It may be consumed at various stages of its development; green leaves, green pods, green peas, dry grains and the straw are excellent animal feed (Sanginga et al., 2003). Its optimum yields have, however, not been realized due to diseases and other limiting factors. Root-gall nematode disease is one of the diseases that cause significant yield and economic losses on cowpea. Nematodes are spread by anything that moves in soil or infested plant material, including field equipment, water running through fields, and infected transplants((Addo-Quaye et al. 2011). These nematodes have wide host ranges, including many vegetable, ornamental, and weed plant species. These nematodes feed on roots, resulting in dysfunctional root systems with reduced water and nutrient absorption (Jones et al., 2013). Poor root function results in above ground symptoms that include plant stunting, wilting, and leaf chlorosis. Affected plants often occur in patches in the field. Root symptoms of root knot nematode include the development of swollen roots areas, called root galls. These galls can be spherical to elongated in shape and vary in size depending on the specific species of Meloidogyne present (Corbett et al., 2011). Symptoms of sting nematode infection include short, stubby roots, and the formation of tight mats of short roots. Once introduced, root knot nematode and sting nematodes are almost impossible to eliminate from the soil. Management is based on an integrated approach involving cultural practices to reduce nematode populations, the use of resistant varieties, and the use of nematicides (Noling, 2012). It is important to lower populations before planting, as there are few effective post planting control options. Amongst the soil bacteria, there is a unique group called rhizobia that have a beneficial effect on the growth of legumes. Rhizobia are remarkable bacteria because they can live either in the soil or within the root nodules of legumes.When legume

Okolie, Henry, Department of Crop Science and Horticulture, Faculty of Agriculture, Nnamdi Azikiwe University, Awka

Ekwuribe, Chukwuemeka, Department of Crop Science, Michael Okpara University of Agriculture, Umudike Obidiebube, Eucharia, Department of Crop Science and Horticulture, Faculty of Agriculture, Nnamdi Azikiwe University, Awka

Obasi, Chiamakai, Department of Crop Science and Horticulture, Faculty of Agriculture, Nnamdi Azikiwe University, Awka 
seeds germinate in the soil, the root hairs come in contact with rhizobia. If the rhizobia and the legume are compatible, a complex process begins during which the rhizobia enter the plant's root hairs (Antoun and Prevost, 2005). Close to the point of entry, the plant develops a root nodule. Once the relationship between plant and rhizobia is established, the plant supplies the rhizobia with energy from photosynthesis and the rhizobiafixatmospheric nitrogen in the nodule, converting it into a form that the plant can use. Both the plant and the rhizobia benefit from such a relationship called a symbiosis. Nodulation is an ecologically and economically important plant phenomenon, in which the symbiosis between plants from the family Fabaceae and the bacteria Igenerarhizobia results in the development of nitrogen fixing nodules on host plant roots. The rhizobia-plant interaction is initiated by Nod factors, which are produced by species-specific rhizobia; The complex process by which the rhizobia produce nitrogen for the legume is called biological nitrogen fixation. Only rhizobia that are specifically compatible with a particular species of legume can stimulate the formation of root nodules, a process called nodulation. This process has great economic benefit for legume production. As a result, rhizobia linoculantsare produced commercially in many countries. Inoculants contain rhizobia isolated from plant nodules and grown (cultured) artificially in the laboratory. If a root nodule is cut open and the inside is pink/red the nodule is active and fixing lots of nitrogen for the plant. The colour is due to the presence of plenty of leghaemoglobin. The redder the nodule, the more active it is. When nodules are young and not yet fixing nitrogen they are white or grey inside. Elaeis guineensisis a tropical forest palm native to West Africa. Grown in plantations it produces 3-8times more oil from a given area than any other tropical or temperate oil crop (Sheil et al., 2009).Oil (triacylglycerols) can be extracted from both the fruit and the seed, crude palm oil (CPO) from the outer mesocarp and palm-kernel oil from the endosperm. Most crude palm oil is used in foods. In contrast, most palm-kernel oil is used in various nonedible products, such as detergents, cosmetics, plastics, surfactants, herbicides, as well as a broad range of other industrial and agricultural chemicals (Wu et al., 2009).

Processing oil palm into palm oil produces large amounts

ofliquidwaste,around55\%to67\%ofthetotalfreshfruit

bunches processed (Igwe and Onyegbado,2007).This fresh waste is in the form of a colloidalsuspensionconsistingof $94-95 \%$ water, $0.7-1 \%$ oil and $\quad 4-5 \%$ total solidsincludingfloatingsolidsof $2-4 \%$. Raworun processed palm oil mille fluent (POME) has a high BOD value around $25,000 \mathrm{mgL}^{-1}$ or more (Wu et al.,2009) hence the POME produced by palm oil companies must be processed in order to have no negative impact on human sort he environment. Although, palm oil mill effluent (POME) is not the only waste

Generated during processing of fresh fruit bunch (FFB) (Khairiah and Khairul, 2006). But it is the most expensive and difficult waste to manage by mill operators. This is because large volumes intones are generate data time. The palm oil industry still considers POME treatment a burden rather than as part of the production process. (Okwute and Isu, 2007).For these obvious reasons, raw
POME or partially treated POME is still being discharged into nearby rivers or land, as this is the easiest and cheapest method for disposal. However, excessive quantities of untreated POME deplete water body of its oxygen and suffocate aquatic life. Many small and big rivers have been devastated by such discharge as people living downs tream are usually affected (Wu et al., 2009). This work examined a profitable way of disposing this organic waste.

\section{EXPERIMENTAL MATERIALS.}

Cowpea cultivars used were: Dan Kano (A1), Borno local (A2) and Sokoto local (A3). They were sourced from Michael Okpara Federal University of Agriculture, Umudike, Nigeria. The palm oil mill effluent (POME) was sourced from an oil mill in Elele in lkwere Local Government Area of Rivers State, Nigeria. The four levels of the POME applications were termed factor as followed 4000lit/ha (B1),6000lit/ha(B2),8000LIT/HA(B3) and Control Olit/ha(B4).The twelve treatments combinations used were $A 1 B 1, A 1 B 2, A 1 B 3$ and $\mathrm{A} 1 \mathrm{~B} 4, \mathrm{~A} 2 \mathrm{~B} 1, \mathrm{~A} 2 \mathrm{~B} 2, \mathrm{~A} 2 \mathrm{~B} 3$ and A2B4,A3B1,A3B2,A3B3 and $A 3 B 4$.The treatment combinations were randomized within each block and replicated three times.

\section{EXPERIMENTAL DESIGN.}

A $3 \times 4$ factorial arrangement that was fitted into randomized complete block design (RCBD) was used for the experiment. Data collected were subjected to analysis of variance and significant means separated by least significant difference (LSD).

\section{CULTURAL PRACTICES.}

Land clearing for dry season planting was done on November26th, 2017 while that for 2018 rainy season was done on April 6th.POME was applied seven days before planting in the different seasons to allow percolation before planting. Planting was done manually at $25 \mathrm{~cm} \times 30 \mathrm{~cm}$.

\section{DATA COLLECTION.}

Soil samples were collected from 0 to $15 \mathrm{~cm}$ depth in all the 12 subplots and composited for analysis before POME application. The Baermann-funnel techniques was used to determine the population of the nematodes based on motality test. The soil $\mathrm{PH}$ was determined electrometrically using EL model $720 \mathrm{PH}$ meter. Other soil parameters were determined using convectional techniques. Composite soil samples were also collected and analyzed towards the end of the experiment. Lengths of roots was determined by carefully digging out and washing the roots with water and measurement with flexible meter tape .Root nodules were manually counted at 4,6 and 8 weeks after planting .Pink colour indicates a functional nodule while dark colour indicates a non -functional nodule. After the final harvest, drying, threashing and winnowing the final grain yield at $14 \%$ moisture content was determined for each plot.

\section{RESULTS:}

(1) Impact of POME rate on root length (cm).

During the first 4WAP, the control plot was significantly higher than other treatments despite cultivar or POME application rate. The trend was also the same during 68WAP with the longest root from the Dan Kano $(26.60 \mathrm{~cm})$ on control plot in 6 WAP rainy season. 
Generally, there was decrease in root length with increase in POME rate.

Table: 1 Impact of POME on Length of roots $(\mathrm{cm})$

\begin{tabular}{|c|c|c|c|c|c|c|c|}
\hline WAP & Wet Season & & & & $\begin{array}{l}\text { Dry } \\
\text { Season }\end{array}$ & & \\
\hline & POMELevei & Dan Kano & $\begin{array}{l}\text { Borno } \\
\text { local }\end{array}$ & $\begin{array}{l}\text { Sokoto } \\
\text { local }\end{array}$ & Dan Kano & $\begin{array}{l}\text { Borno } \\
\text { local }\end{array}$ & $\begin{array}{l}\text { Sokoto } \\
\text { local }\end{array}$ \\
\hline \multirow[t]{4}{*}{ 4WAP } & Control & 18.5 & 18.00 & 20.23 & 17.17 & 11 & 22.23 \\
\hline & 4000l/ha & 17.17 & 12.67 & 19.33 & 16.83 & 12.50 & 17.00 \\
\hline & 6000l/ha & 13.83 & 11.83 & 19.33 & 15.50 & 11.17 & 16.67 \\
\hline & $80001 / h a$ & 10.83 & 10.43 & 15.33 & 9.43 & 9.33 & 13.43 \\
\hline \multirow[t]{4}{*}{ 6WAP } & Control & 26.60 & 24.67 & 21.37 & 26.23 & 18.17 & 18.17 \\
\hline & 4000l/ha & 25.93 & 21.67 & 19.50 & 17.73 & 15.00 & 15.67 \\
\hline & $6000 \mathrm{l} / \mathrm{ha}$ & 24.77 & 20.67 & 18.77 & 15.00 & 14.67 & 12.33 \\
\hline & $8000 \mathrm{l} / \mathrm{ha}$ & 23.17 & 18.67 & 15.87 & 11.93 & 11.93 & 12.07 \\
\hline \multirow[t]{4}{*}{ 8WAP } & Control & 20.43 & 19.00 & 22.87 & 19.23 & 19.07 & 22.50 \\
\hline & 4000l/ha & 18.33 & 18.33 & 19.00 & 17.20 & 17.87 & 20.00 \\
\hline & 6000l/ha & 17.83 & 16.83 & 18.17 & 15.25 & 14.83 & 16.57 \\
\hline & $8000 \mathrm{l} / \mathrm{ha}$ & 17.07 & 16.83 & 18.17 & 14.83 & 14.90 & 16.77 \\
\hline LSD & & & 0.56 & & & 0.51 & \\
\hline
\end{tabular}

(2) Impact of POME rate on number of functional root nodules.

At 4WAP Bornu local had the highest functional nodules (38) on 8000l/ha plot in the dry season. During 6 -8 WAP, there was significant difference on the effects of different POME rates. Sokoto local had the highest number of functional nodules (50) in dry season of plots with 8000i/ha POME rate.

Generally, there was increase in the number of functional nodules with increase in POME rates.

Table: 2 Impact of POME on Number of Functional Nodules

\begin{tabular}{|c|c|c|c|c|c|c|c|}
\hline & Wet Season & & & & $\begin{array}{l}\text { Dry } \\
\text { Season }\end{array}$ & & \\
\hline & POMELevei & Dan Kano & $\begin{array}{l}\text { Borno } \\
\text { local }\end{array}$ & $\begin{array}{l}\text { Sokoto } \\
\text { local }\end{array}$ & Dan Kano & $\begin{array}{l}\text { Borno } \\
\text { local }\end{array}$ & $\begin{array}{l}\text { Sokoto } \\
\text { local }\end{array}$ \\
\hline 4WAP & Control & 10 & 8 & 16 & 8 & 11 & 15 \\
\hline 4WAP & 4000l/ha & 9 & 9 & 12 & 6 & 9 & 16 \\
\hline 4WAP & $60001 /$ ha & 16 & 12 & 30 & 16 & 28 & 30 \\
\hline 4WAP & $8000 \mathrm{l} / \mathrm{ha}$ & 21 & 20 & 26 & 24 & 38 & 34 \\
\hline 6WAP & Control & 12 & 11 & 18 & 9 & 14 & 18 \\
\hline 6WAP & 4000l/ha & 10 & 11 & 13 & 7 & 11 & 17 \\
\hline 6WAP & $6000 \mathrm{l} / \mathrm{ha}$ & 18 & 18 & 26 & 25 & 27 & 31 \\
\hline 6WAP & 8000 l/ha & 29 & 21 & 31 & 39 & 34 & 50 \\
\hline 8WAP & Control & 10 & 12 & 22 & 11 & 12 & 12 \\
\hline 8WAP & 4000l/ha & 12 & 10 & 16 & 11 & 13 & 24 \\
\hline 8WAP & $6000 \mathrm{l} / \mathrm{ha}$ & 21 & 10 & 31 & 29 & 24 & 35 \\
\hline 8WAP & $8000 \mathrm{l} / \mathrm{ha}$ & 35 & 22 & 36 & 37 & 28 & $39 s$ \\
\hline LSD & & & 0.69 & & & 0.75 & \\
\hline
\end{tabular}


(3) Impact of POME rate on the number of non functional nodules.

During the first 4WAP, all the cultivars despite season recorded the highest number of non-functional nodules in control plots. The same trend followed in 6-8 WAP with the highest number (15) in Sokoto local on $4000 \mathrm{l} / \mathrm{ha}$ plots 8 WAP dry season. Comparatively, increasing POME level decreased number of non-functional nodules significantly.

Table: 3 Impact of POME on Number of Non-Functional Nodules

\begin{tabular}{|c|c|c|c|c|c|c|c|}
\hline & Wet Season & & & & $\begin{array}{l}\text { Dry } \\
\text { Season }\end{array}$ & & \\
\hline & POMELevei & Dan Kano & $\begin{array}{l}\text { Borno } \\
\text { local }\end{array}$ & $\begin{array}{l}\text { Sokoto } \\
\text { local }\end{array}$ & Dan Kano & $\begin{array}{l}\text { Borno } \\
\text { local }\end{array}$ & $\begin{array}{l}\text { Sokoto } \\
\text { local }\end{array}$ \\
\hline \multirow[t]{4}{*}{ 4WAP } & Control & 6 & 4 & 6 & 7 & 6 & 7 \\
\hline & 4000l/ha & 4 & 5 & 3 & 7 & 7 & 5 \\
\hline & $60001 /$ ha & 4 & 4 & 3 & 5 & 5 & 4 \\
\hline & 8000 l/ha & 3 & 3 & 2 & 4 & 3 & 1 \\
\hline \multirow{4}{*}{ 6WAP } & Control & 5 & 4 & 10 & 7 & 7 & 13 \\
\hline & 4000l/ha & 7 & 3 & 6 & 5 & 5 & 8 \\
\hline & 6000l/ha & 4 & 2 & 4 & 4 & 5 & 7 \\
\hline & $8000 \mathrm{l} / \mathrm{ha}$ & 4 & 2 & 4 & 4 & 4 & 5 \\
\hline \multirow[t]{4}{*}{ 8WAP } & Control & 6 & 6 & 11 & 5 & 9 & 9 \\
\hline & 4000I/ha & 10 & 5 & 11 & 4 & 8 & 15 \\
\hline & 6000I/ha & 6 & 4 & 6 & 3 & 6 & 8 \\
\hline & 8000I/ha & 6 & 2 & 3 & 3 & 4 & 7 \\
\hline LSD & & & 0.82 & & & 2.14 & \\
\hline
\end{tabular}

(4) Impact of POME on Nematode population. Control plots had the highest number of Nematode (Meloidogyneinconita) (8,553). The least Nematode population was recorded $8000 \mathrm{l} /$ ha plots. Higher POME levels negatively affected nematode population and favoured nitrogen fixing Rhizobium population.

Table: 4 Impact of POME on Nematode populations.

\begin{tabular}{lllll}
\hline & & Wet Season & & Dry Season \\
\hline POME Level & Before & After & Before & After \\
& Application & Application & Application & Application \\
Control & 8553 & 8554 & 6695 & 6697 \\
4000lit/ha & 8553 & 8554 & 6695 & 6149 \\
6000lit/ha & 8553 & 2632 & 6695 & 2001 \\
\hline 8000lit/ha & 8553 & 3005 & 6695 & 1660 \\
\hline
\end{tabular}

(5) Impact of POME on dry seed matter yield(t/ha)

Generally, as the rate of POME application increased, the seed yield increased. The least yield was recorded in control plots. Sokoto local had higher yields irrespective of season. It had the highest yield (0.3t/ha) in wet season on $80001 /$ ha POME plot. 
Table: 5 Dry matter yield (t/ha)

\begin{tabular}{|c|c|c|c|c|c|c|}
\hline & & $\begin{array}{l}\text { WET } \\
\text { SEASON }\end{array}$ & & & $\begin{array}{l}\text { DRY } \\
\text { SEASON }\end{array}$ & \\
\hline $\begin{array}{l}\text { POME } \\
\text { LEVELS }\end{array}$ & Dan Kano & Borno local & Sokoto local & Dan Kano & Borno local & Sokoto local \\
\hline $\begin{array}{l}\text { Control } \\
\text { Olit/ha }\end{array}$ & 0.17 & 0.26 & 0.24 & 0.14 & 0.15 & 0.15 \\
\hline 4000lit/ha & 0.15 & 0.24 & 0.24 & 0.18 & 0.18 & 0.18 \\
\hline 6000lit/ha & 0.23 & 0.27 & 0.26 & 0.24 & 0.22 & 0.23 \\
\hline 8000 lit/ha & 0.25 & 0.25 & 0.30 & 0.16 & 0.25 & 0.24 \\
\hline LSD & 0.15 & & & 0.12 & & \\
\hline
\end{tabular}

\section{DISCUSSION}

During the course of the work the control plots had longer roots than POME applied plots. This showed that POME when newly applied negatively affected cowpea roots growth and development (Osaigbovo and Orhue, 2011). The raw or partially treated POME has an extremely high content of degradable organic matter, which is due in part to the presence of unrecovered palm

Oil(Ahmad et al.,2008).Oil generally reduces penetration of sunlight there by reducing soil temperation. It also reduces soil aeration by blocking the soil pore spaces, reduces solubility of soluble minerals and root hairs absorption ability (Osaigbovi and Orhue, 2011).Most of cowpea roots are found near the soil surface, therefore they were highly affected by POME application especially during the first 4WAP.In most of the cultivars and rates of POME rates, functional root nodules were more in dry season, this might be due to the soothing effect of POME(McGill,1980).This was also why higher POME levels reduced number of non functional root nodules. The control plots had the highest population of root knot nematode (Meloidogyneincongnita) while the $8000 \mathrm{l} / \mathrm{ha}$ had the least. Higher POME rates negatively affected nematode population to the advantage of nitrogen fixing bacteria population. This could be attributed to the ability of Rhizobium bacteria to decompose and make use of the POME useful nutrients(Nwoko and Ogunyemi, 2010). Since there is always an increased atmospheric Nitrogen fixation during oil decomposition phase by soil bacteria (McGill,1980) there was high yields of cowpea in $80001 /$ ha plots. This high yields was also attributed the release of useful POME nutrients like phosphorus(Iwara et al., 2011) and calcium by soil bacteria (Qgboi et al.,2010).This work showed that POME, an organic waste can be effectively be applied on farm land at up to $8000 \mathrm{I} / \mathrm{ha}$ for cowpea cultivation, especially Sokoto local.

\section{REFERENCES}

Addo-Quaye, A. A., Darkwa, A. A., and Ampian, M.K.P., 2011. Performance of three cowpea (Vigna unguiculata [L.] Walp) varieties in two agroecological zones of the Central Region of Ghana II: Grain yields and its components. ARPN Journal of Agricultural and Biological Science 6 (2): 1-9.

Ahmad AL, Chan CY, Abd-Shukor SR, Mashitah, M. D., 2008: Recovery of oil and carotenes from palm oil mill effluent (POME). Chem. Eng. J 141: 383 - 386.

Antoun, H. and Prevost, D., 2005. Ecology of plant growth promoting rhizobacteria. In Siddiqui, $\mathbf{Z}$. A., Ed. PGPR: Biocontrol and Biofertilization.

Springer, New York, NY, pp. 1-38.

Corbett BP, Jia L, Sayler RJ, Arevalo-Soliz LM, Goggin F., 2011. The effects of root-knot nematode infection and Mi-mediated nematode resistance in tomato on plant fitness. J Nematology. 43: 8289.

Khairiah, B. and Khairul, A. M. A., 2006: Bio composites from oil palm resources. Journal of Oil Palm Research, April, 103-113.

Igwe, J. C. and C. C. Onyegbado, 2007. A Review of Palm Oil Mill Effluent (Pome) Water Treatment, Global.

Journal of Environmental Research.,1(2): 54-62.

Iwara AI, Ewa EE, Ogundele FO, Adeyemi JA., 2011: Ameliorating Effects of Palm Oil Mill Effluent on the Physical and Chemical Properties of Soil in Ugep, Cross River State, South-Southern Nigeria. Intl. J. App. Sci. Technol1(5): 106 112.

Jones JT, Haegemen A, Danchin EGJ, Gaur HS, Helder J, Jones MGK, Kikuchi T, Palomares-Rius JE, Wesemael WML, Perry RN., 2013 Top 10 plantparasitic nematodes in molecular plant pathology. Mol Plant Pathol. 14: 946-961.

Langyintuo, A.S., Lowenberg-DeBoer, J. Faye, M. Ibro, G. Moussa, B. Kergna, A. Kushwaha, S. Musa, S. Ntoukam G., 2003. Cowpea supply and demand in West and Central Africa. Field Crops Research 82 215-231

McGill, W. B., 1980 Factors that affect oil degradation rates in the soil. In disposal of industrial waste and oily sludge by land cultivation. Resources System Management Association pp.103-122.

Noling JW., 2012 Nematode management in carrots, University of Florida, IFAS Extension, ENY021,1-13. 
Nwoko CO, Ogunyemi S., 2010: Evaluation of palm oil mill effluent to maize (Zea mays L) crop: Yields, tissue nutrient content and residual soil chemical properties. Aust. J. Crop Sci. 4: 16 - 22

Nwoko CO, Ogunyemi S., 2010: Effect of Palm oil mill effluent (POME) on microbial characteristics in a humid tropical soil under laboratory conditions. Intl. J. Environ. Sci. Dev. 1(4): 307 - 314..

Ogboi E, Kperegbeyi JI, Nmor El, Odeh HO., 2010: The performance of maize (Zea mays) in soil contaminated with palm oil mill effluent (POME) in South, South Central Nigeria. Afr. J. Gen. Agric6: 19 - 24. 2010.

Olagunju F. I., 2008: Economics of palm oil processing in South Western Nigeria. Int. J. Agric. Econs. Rural Dev1(2): 69 - 77.

Osaigbovo AU, Orhue ER., 2011: Effect of palm oil mill effluent on some soil chemical properties and growth of maize (Zea mays L). Nig. J. Agric Food Environ 7(3): 51 - 54. 2011.

Okwute, O.L, N.R Isu., 2007: Impact analysis of palm oil mill effluent on the aerobic bacterial density and ammonium oxidizers in a dumpsite in Anyigba,
Kogi State. African Journal of Biotechnology, 6(2): 116-119.

Sanginga, N., Dashiell, K., Diels, J., Vanlauwe, B., Lyasse, O., Carsky, R. J., Tarawali, S., Asafo-Adjei, B., Menkir, A., Schulz, S., Singh, B. B., ChikoyeD., Keatinge, D. and Rodomiro, O., 2003.Sustainable resource management coupled to resilient germplasm to provide new intensive cereal-grain legume livestock systems in the dry savanna. Agriculture, Ecosystems and Environment 100: 305-314.

Sheil, D., Casson, A., Meijaard, E., van Nordwijk, M. Gaskell, J., Sunderland-Groves, J., Wertz, K. and Kanninen, M. 2009. The impacts and opportunities of oil palm in Southeast Asia: What do we know and what do we need to know? Occasional paper no. 51.CIFOR, Bogor, Indonesia.

Wu T.Y., A.W. Mohammad, J. Jahim, N. Anuar 2009: A holistic approach to managing palm oil mill effluent

POME: Biotechnological advances in the sustainable reuse of POME. Biotechnology Advances, 27(1):

40-52. 